\title{
Modelowanie 1D procesów generowania węglowodorów z warstw istebniańskich w profilu odwiertu nawiercającego utwory jednostki śląskiej
}

\author{
1D modelling of hydrocarbon generation from the Istebna Beds in borehole profile from \\ the Silesian Unit
}

\author{
Karol Spunda \\ Instytut Nafty i Gazu - Państwowy Instytut Badawczy
}

\begin{abstract}
STRESZCZENIE: W niniejszej pracy przeprowadzono analizę generacyjną warstw istebniańskich z jednostki śląskiej na przykładzie profilu otworu wiertniczego zlokalizowanego w rejonie Dukli. Numeryczne modelowanie przeprowadzono z wykorzystaniem programu PetroMod 1D. Modelowaniu poddano poziom dolnych warstw istebniańskich o miąższości 162 metrów. W celu określenia typu genetycznego substancji organicznej przeprowadzono analizę pirolityczną Rock Eval. Na podstawie badań geochemicznych stwierdzono, że substancja organiczna rozproszona w skale macierzystej zbudowana jest z gazotwórczego kerogenu III typu. Analizowana formacja skalna charakteryzuje się dobrymi parametrami macierzystości. Początkową ilość węgla organicznego w niej rozproszonego oszacowano na 2,70\%. Modelowanie miało na celu określenie potencjału węglowodorowego wydzielonych skał macierzystych (tj. ilości wygenerowanych węglowodorów), rekonstrukcję historii rozwoju basenu naftowego oraz odtworzenie warunków termicznych w nim panujących. W oparciu o dostępne dane laboratoryjne, takie jak wartości parametru $T_{\max }$ oraz pomiary porowatości, oszacowano paleomiąższości warstw skalnych usuniętych w wyniku erozji oraz wielkość tej erozji którą przyjęto na 2100 metrów. W wyniku przeprowadzonego modelowania stwierdzono, że stopień transformacji kerogenu w analizowanych warstwach osiągnął $29 \%$. Generacja węglowodorów rozpoczęła się najprawdopodobniej w oligocenie, kiedy to skała macierzysta pogrążona została na głębokość około 2000 metrów, a zakończyła się w miocenie. Ilość wygenerowanych węglowodorów, oszacowana na podstawie modelowania, wyniosła około 0,62 milionów ton z 1 km² skały macierzystej, przy jej miąższości wynoszącej 162 metry.
\end{abstract}

Słowa kluczowe: modelowanie procesów generacyjnych 1D, PetroMod, warstwy istebniańskie, potencjał węglowodorowy.

ABSTRACT: The paper is focused on petroleum analysis of Istebna Beds in the profile of the borehole located within the Silesian Unit in the Dukla commune. Numerical modeling was carried out using the PetroMod 1D software. 162 meters thick layer of Lower Istebna beds was subjected to modeling. Based on geochemical studies, it was found that the organic matter dispersed in the source rock contains type III kerogen and this rock formation have a good petroleum potential. Organic carbon content in source rock was $2,70 \%$. Modeling was aimed at determining the hydrocarbon potential of source rocks (the amount of generated hydrocarbons), reconstruction the history of the evolution of the sedimentary basin and reconstruction of the thermal history prevailing in the basin. Based on available laboratory data such as the $\mathrm{T}_{\max }$ values and porosity measurements, paleothickness of removed beds was estimated and the erosion was determined at 2100 meters. As a result of the modeling, it was found that the transformation ratio of kerogen in the source rock reached 29\%. The generation of hydrocarbons began in the Oligocene, when the source rock was buried to a depth of about 2000 meters and ended in Miocene. Quantity of generated hydrocarbons was about 0.62 million tons from $1 \mathrm{~km}^{2}$ of 162 meters thick source rock.

Key words: 1D modeling of hydrocarbon generation, PetroMod, Istebna Beds, hydrocarbon potential.

\section{Wstęp}

W niniejszej pracy przeprowadzono jednowymiarowe modelowanie procesów naftowych dla warstw istebniańskich z jednostki śląskiej na przykładzie otworu wiertniczego zlokalizowanego w gminie Dukla. Modelowanie systemu naftowego jest techniką numerycznego modelowania procesów fizycznych i chemicznych, które zachodzą w obrębie basenu sedymentacyjnego, prowadzących do powstania złoża. Jego podstawę stanowi odtworzenie rozwoju geologicznego

Autor do korespondencji: K. Spunda, e-mail: karol.spunda@inig.pl

Artykuł nadesłano do Redakcji: 16.05.2019 r. Zatwierdzono do druku 30.01.2020 r 
obszaru badań. Wykorzystywane jest ono do rekonstrukcji historii termicznej basenu, kontrolującej generację węglowodorów, oraz czasowego umiejscowienia procesów zachodzących w jego obrębie (powstanie skały macierzystej, zbiornikowej, uszczelniającej, skał nadkładu oraz generacja i ekspulsja węglowodorów) (Hermanrud, 1993; Hantschel i Kauerauf, 2009; Brzuszek 2015). Zdefiniowanie rodzaju i miąższości skał macierzystych, rekonstrukcja pierwotnych wartości potencjału węglowodorowego kerogenu $\left(\mathrm{HI}_{0}\right)$ i oszacowanie początkowych zawartości substancji organicznej rozproszonej w skale macierzystej $\left(\mathrm{TOC}_{0}\right.$ ) pozwala na określenie ilości wygenerowanych z niej węglowodorów. Podstawą prawidłowego przeprowadzenia modelowania jest kalibracja modelu geologicznego i termicznego. W przypadku modelu geologicznego wykonuje się to, opierając się na danych z pomiarów porowatości skał oraz ciśnienia porowego, a w przypadku modelu termicznego - opierając się na wartościach refleksyjności witrynitu i pomiarów temperatur w otworze.

Przeprowadzony w ramach niniejszej pracy proces modelowania objął macierzysty poziom dolnych warstw istebniańskich o miąższości 162 m. Modelowanie 1D wykonano z wykorzystaniem oprogramowania PetroMod 2016.

\section{Zarys budowy geologicznej obszaru badań wraz z charakterystyką elementów systemu naftowego}

\section{Charakterystyka sukcesji osadowej jednostki śląskiej}

Karpaty zewnętrzne, zwane często fliszowymi, należą do największej prowincji naftowej centralnej Europy i są jednym z pierwszych obszarów, na którym rozpoczęto eksploatację złóż węglowodorów. Na ich terenie odkryto 83 złoża ropy i gazu w obrębie różnych formacji litostratygraficznych (Kotarba et al., 2014).

Obszar badań znajduje się we wschodniej części jednostki śląskiej, w obrębie fałdu Iwonicza-Zdroju. Najstarszymi znanymi utworami w obrębie jednostki śląskiej są ciemnoszare mułowce i łupki margliste, opisywane jako dolne łupki cieszyńskie (Bieda et al., 1963). Ich wiek określa się w literaturze polskiej najczęściej na kimeryd-tyton (Olszewska et al., 2008), podczas gdy na terenie Czech ich wiek udokumentowano na oksford do późnego tytonu (Menčík et al., 1983), a miejscami możliwy jest nawet wczesny berias (Skupien, 2003). Część z tych osadów powstała w wyniku podwodnych ruchów osuwiskowych. Wyżej w profilu zalegają warstwy wapieni cieszyńskich, reprezentowane przez turbidytowe wapienie oraz margle wieku późny tyton-walanżyn, a lokalnie nawet wczesny hoteryw (Olszewska et al., 2008), o miąższości osiągającej $200 \mathrm{~m}$. Kolejnym ogniwem są znane z całego obszaru jednostki śląskiej górne łupki cieszyńskie (walanżyn-hoteryw) wykształcone w postaci ciemnoszarych łupków marglistych z przewarstwieniami cienko- oraz średnioławicowych piaskowców wapnistych. W czasie hoterywu-barremu miała miejsce sedymentacja piaskowców i zlepieńców (o miąższości do $200 \mathrm{~m}$ ), zwanych piaskowcami grodziskimi (Oszczypko, 2011). Kolejnym ogniwem litostratygraficznym są ciemne łupki ilaste i skrzemionkowane, zawierające ławice i konkrecje sferosyderytów, wydzielane jako łupki wierzowskie (wieku barrem-apt). W czasie albu i wczesnego cenomanu (Hanzlíková, 1966, Picha et al., 2006) miała miejsce sedymentacja warstw lgockich, wykształconych jako cienkoławicowe piaskowce gruboziarniste oraz zlepieńce, które ku górze przechodzą w cienko- i średnioławicowe piaskowce kwarcowe z przewarstwieniami zielonkawych łupków. Na północ od Sanoka warstwy lgockie przechodzą w dobrze wysortowane jasnoszare piaskowce z igłami gąbek (warstwy gezowe). Wyżej w profilu występuje seria zielonych łupków z wtrąceniami czarnych łupków oraz licznymi wkładkami radiolarytów i piaskowców krzemionkowych, wydzielanych jako formacja łupków radiolariowych z Barnasiówki, której wiek określa się na późny cenoman - wczesny turon (Bąk et al., 2001). Ponad nimi położona jest seria łupków pstrych, znanych ze wszystkich jednostek tektonicznych Karpat zewnętrznych. W okresie późnej kredy nastąpiło zasilenie basenu materiałem klastycznym. Zaowocowało to sedymentacją warstw godulskich, wykształconych w formie grubo- oraz cienkoławicowych piaskowców przewarstwianych zielonymi łupkami, o sumarycznej miąższości do $2000 \mathrm{~m}$. Warstwy godulskie występują głównie w zachodniej i centralnej części jednostki śląskiej. W kierunku północnym i wschodnim utwory te przechodzą w pstre łupki. Kolejne ogniwo litostratygraficzne stanowią warstwy istebniańskie, których miąższość lokalnie osiąga 1700 m. Ich wiek określany jest na senon-paleocen, przy czym granica pomiędzy senonem a paleocenem przebiega w dolnej części warstw istebniańskich górnych (Golonka i Waśkowska-Oliwa, 2007). Warstwy te w spągowej części wykształcone są w formie gruboziarnistych fluksoturbidytów oraz zlepieńców o dużej miąższości. Górną cześć profilu warstw istebniańskich tworzą lekko wapniste, grubowarstwowe zlepieńce oraz piaskowce pokryte ciemnoszarymi łupkami osiągającymi miąższość do $200 \mathrm{~m}$. Charakterystyczną litofacją są łupki pstre, których wiek szacuje się na późny paleocen - wczesny eocen (Cieszkowski, 1992; Golonka i Waśkowska-Oliwa, 2007), o miąższości około $500 \mathrm{~m}$. Z łupkami pstrymi przeławicają się piaskowce ciężkowickie, które mogą tworzyć wiele poziomów i soczewek gruboławicowych fluksoturbidytów oraz zlepieńców. W czasie środkowego i późnego eocenu miała miejsce naprzemienna sedymentacja zielonoszarych łupków i cienko warstwowanych piaskowców, wyróżnianych jako warstwy hieroglifowe. Ku górze przechodzą one w zielone łupki, a następnie 
margle globigerynowe (Waśkowska, 2015). Jedynie w południowej części jednostki śląskiej górny eocen wykształcony jest w postaci piaskowców gruboławicowych. W czasie sedymentacji późnooligoceńskiej powstały czarne łupki bitumiczne (łupki menilitowe), które lokalnie w południowej części jednostki zastępowane są przez cienkoławicowe piaskowce wapniste - piaskowce cergowskie (Pszonka i Wendorff, 2017). W obrębie warstw menilitowych występują piaskowce magdaleńskie (Dziadzio, 2015). Utwory te powstały w warunkach płytkiego morza (Dziadzio, 2018). Najmłodszą jednostkę litostratygraficzną stanowią warstwy krośnieńskie, których wiek określa się na oligocen i wczesny miocen (Koszarski i Żytko, 1959; Jucha i Kotlarczyk, 1961; Bieda et al., 1963; Jankowski, 1996). Warstwy te w dolnej części wykształcone są jako grubo- i średnioławicowe piaskowce wapniste, które ku górze przechodzą w piaskowce z szarymi łupkami marglistymi. Udział pakietów łupkowych na ogół wzrasta ku górze. Litofacje warstw krośnieńskich w obrębie jednostki śląskiej są diachroniczne.

\section{Skaly macierzyste}

Na badanym obszarze za główną skałę macierzystą uznawane są łupki menilitowe. Ilość węgla organicznego rozproszonego w tych utworach dochodzi do $17 \%$, a stopień dojrzałości termicznej substancji organicznej osiągnął wczesną fazę niskotemperaturowych procesów termogenicznych. Alternatywnym poziomem spełniającym kryteria macierzystości są warstwy istebniańskie. Charakteryzują się one gorszymi parametrami macierzystości niż łupki menilitowe (ilość węgla organicznego waha się od dziesiątych części procenta do około 4\%), jednak materia organiczna zawarta $\mathrm{w}$ tych skałach osiągnęła wyższy stopień dojrzałości termicznej niż w przypadku utworów menilitowych. Dodatkowo jako potencjalne skały macierzyste rozpatrywać można warstwy wierzowskie i lgockie, charakteryzujące się średnim potencjałem generacyjnym (Dziadzio et al., 2006; Kosakowski et al., 2009; Spunda i Matyasik, 2019).

\section{Skaly zbiornikowe}

Głównymi skałami zbiornikowymi w omawianym obszarze są piaskowce warstw istebniańskich. W ich obrębie wyróżniane są dwa ogniwa: warstwy istebniańskie dolne oraz warstwy istebniańskie górne. Miąższości tych wydzieleń wahają się od $300 \mathrm{~m}$ do $2000 \mathrm{~m}$ Porowatość piaskowców osiąga wartości od $0,5 \%$ do $36,8 \%$. W obrębie piaskowców istebniańskich wyróżnia się dwie główne facje: turbidytów niskogęstościowych i wysokogęstościowych (Dziadzio et al., 2006). Wysokogęstościowe turbidyty charakteryzują się lepszymi parametrami zbiornikowymi niż turbidyty niskogęstościowe. Wiąże się to z obecnością średnio i dobrze wysortowanych ziaren budujących piaskowce średnio- i gruboziarniste. Kolejną skałą zbiornikową jest piaskowiec ciężkowicki (eocen). Jego porowatość waha się od $10 \%$ do $25 \%$ przy średniej wartości około 13\%. Jako dodatkowe skały zbiornikowe traktować można piaskowce magdaleńskie (oligocen), których porowatość osiąga $25 \%$, a miąższość dochodzi do $70 \mathrm{~m}$, warstwy krośnieńskie, o porowatości dochodzącej do 9,4\% (obszar Gorlic i Krosna), a także warstwy lgockie i godulskie (Karnkowski, 1993; Dziadzio et al., 2006).

\section{Odkryte ztoża węglowodorów}

W obrębie jednostki śląskiej rozpoznano dotąd szereg złóż ropy naftowej i gazu ziemnego. Najbliżej modelowanego otworu znajduje się odkryte w 1890 roku wielosegmentowe złoże ropy naftowej Iwonicz-Zdrój-Zboiska-Draganowa. Złoże to usytuowane jest w obrębie antykliny Iwonicza-Zdroju, w poziomach piaskowców ciężkowickich oraz istebniańskich, i tworzy kilka oddzielnych stref złożowych. Ze złoża wydobyto ogółem ponad 310 tys. ton ropy naftowej i $120 \mathrm{mln} \mathrm{\textrm {m } ^ { 3 }}$

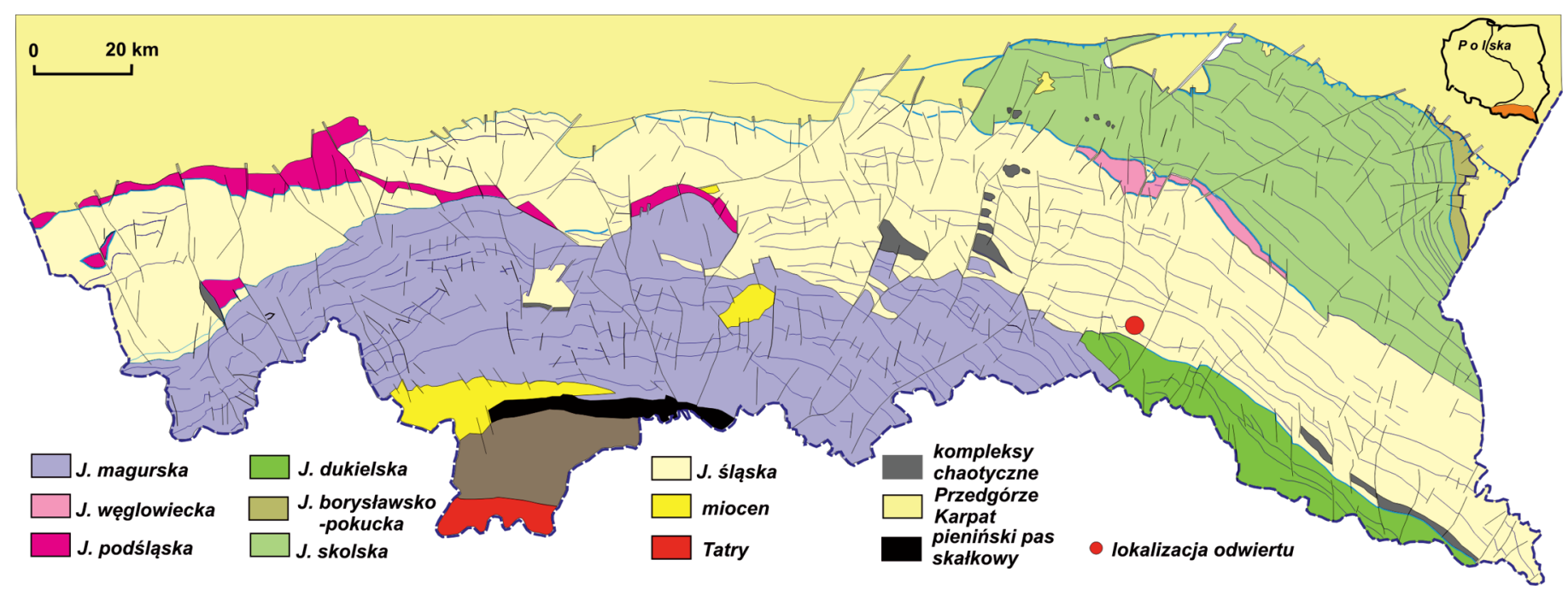

Rys. 1. Mapa polskich Karpat z lokalizacją odwiertu (za: Jankowski i Probulski, 2011 - zmodyfikowana)

Fig. 1. Map of the Polish Carpathian showing borehole location (after Jankowski \& Probulski, 2011 - modified) 
gazu (Karnkowski, 1993). Największym złożem gazu ziemnego w Karpatach jest odkryte w 1928 roku złoże Strachocina. Uzyskano z niego ponad 4,5 $\mathrm{mld}^{3}$ gazu. Złoże znajduje się w centralnej części fałdu Strachocina-Sanok. Struktura Strachociny tworzy antyklinę, w której skałą zbiornikową są piaskowce istebniańskie uszczelnione łupkami istebniańskimi. Złożem ropno-gazowym jest odkryte w 1953 roku złoże Osobnica, usytuowane w strukturze fałdu Bóbrki-Osobnicy. Uzyskano z niego ponad 540 tys. ton ropy naftowej oraz $70 \mathrm{mln} \mathrm{m}^{3}$ gazu ziemnego. Skałę zbiornikową tworzą piaskowce ciężkowickie oraz górne i dolne piaskowce istebniańskie. Innym przykładem złoża warstwowego jest złoże Czarna, które składa się z 11 horyzontów produktywnych, odkryte w 1936 roku. Zlokalizowane jest w strukturze antyklinalnej Czarna-Lipie, a kolektorem są silnie spękane piaskowce dolnokrośnieńskie (Karnkowski, 1993; Dziadzio et al., 2006).

\section{Budowa i kalibracja modelu}

Pierwszym etapem modelowania rozwoju basenu sedymentacyjnego oraz procesów w nim zachodzących była budowa i kalibracja modelu geologicznego, polegająca na odtworzeniu historii pogrzebania osadów. Realizuje się to na podstawie danych stratygraficznych oraz sejsmicznych pozwalających na przypisanie każdemu z przyjętych wydzieleń litologicznych obecnej głębokości zalegania jego stropu i spągu, a także określenia przybliżonego czasu początku i końca jego depozycji. Dodatkowo uwzględnia się główne wydarzenia erozyjne, szacując ich interwały czasowe oraz paleomiąższości zerodowanych osadów, a także określa paleobatymetrię basenu sedymentacyjnego (rys. 2, tab. 1) (Welte et al., 1983). Dla każdego wydzielenia konieczne było zdefiniowanie litotypu, czyli określenie stosunków procentowych w odniesieniu do wykształcenia litologicznego budujących go skał. Niezbędne do tego informacje pozyskuje się m.in. $\mathrm{z}$ analizy opisów rdzeni oraz próbek okruchowych. Następnie każdemu wydzieleniu przypisano rolę w systemie naftowym (skała macierzysta, skały podłoża, skały nadkładu). Dzięki wartościom porowatości uzyskanych w wyniku interpretacji pomiarów geofizyki otworowej, a także wyników badań laboratoryjnych możliwe było opracowanie modelu kompakcji oraz jego kalibracja (rys. 3). Na podstawie tego modelu oszacowano miąższość osadów poddanych erozji, co wiąże się bezpośrednio z maksymalną głębokością pogrzebania skał macierzystych, a co za tym idzie - reżimem termicznym, w jakim się znajdowały. Wielkość erozji oszacowano na $2100 \mathrm{~m}$.

Kolejnym etapem była budowa i kalibracja modelu termicznego. W tym celu zdefiniowano litotypy występujące w profilu otworu, wpływające na odmienne parametry termiczne skał, takie jak ciepło radiogeniczne, pojemność oraz przewodność cieplna. Następnie ustalono warunki brzegowe dla budowanego modelu (rys. 4). Są nimi gęstość paleostrumienia cieplnego podłoża (heat flow - HF) oraz wartości średnich rocznych

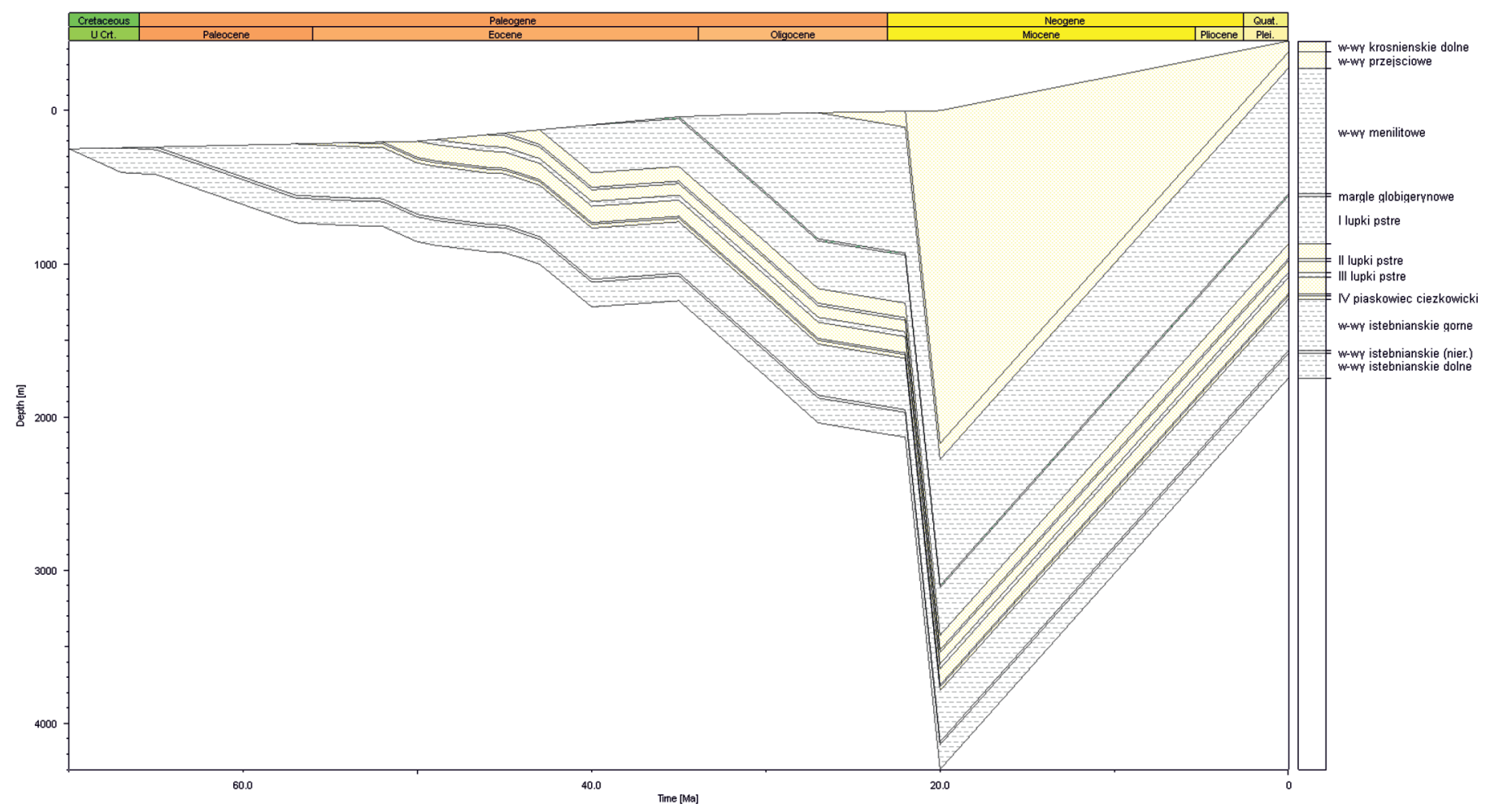

Rys . 2. Historia pogrzebania utworów w profilu otworu

Fig. 2. Burial history plot of beds in the analysed borehole profile 
Tabela 1. Dane wejściowe do budowy modelu

Table 1. Model inputs

\begin{tabular}{|c|c|c|c|c|c|c|c|c|c|}
\hline \multirow[t]{2}{*}{ Warstwa } & 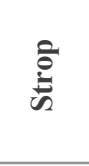 & $\stackrel{\infty}{\varpi}$ & 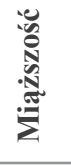 & 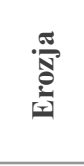 & 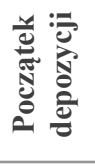 & 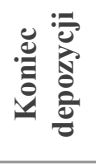 & 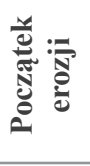 & 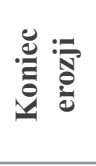 & \multirow[t]{2}{*}{$\begin{array}{c}\text { Element } \\
\text { systemu } \\
\text { naftowego }\end{array}$} \\
\hline & \multicolumn{4}{|c|}{$[\mathrm{m}]$} & \multicolumn{4}{|c|}{ [mln lat] } & \\
\hline Warstwy krośnieńskie dolne & -454 & -382 & 72 & 2100 & 22 & 20 & 10 & 0 & skały nadkładu \\
\hline Warstwy przejściowe & -382 & -278 & 104 & & 27 & 22 & & & skały nadkładu \\
\hline Warstwy menilitowe & -278 & 545 & 823 & & 35 & 27 & & & skały nadkładu \\
\hline Margle globigerynowe & 545 & 558 & 13 & & 40 & 35 & & & skały nadkładu \\
\hline I hupki pstre & 558 & 870 & 312 & & 43 & 40 & & & skały nadkładu \\
\hline Piaskowiec ciężkowicki & 870 & 965 & 95 & & 45 & 43 & & & skały nadkładu \\
\hline II hupki pstre & 965 & 982 & 17 & & 46 & 45 & & & skały nadkładu \\
\hline II piaskowiec ciężkowicki & 982 & 1057 & 75 & & 49 & 46 & & & skały nadkładu \\
\hline III łupki pstre & 1057 & 1089 & 32 & & 50 & 49 & & & skały nadkładu \\
\hline III piaskowiec ciężkowicki & 1089 & 1195 & 106 & & 52 & 50 & & & skały nadkładu \\
\hline IV łupki pstre & 1195 & 1207 & 12 & & 54 & 52 & & & skały nadkładu \\
\hline IV piaskowiec ciężkowicki & 1207 & 1231 & 24 & & 57 & 54 & & & skały nadkładu \\
\hline Warstwy istebniańskie górne & 1231 & 1566 & 335 & & 65 & 57 & & & skały nadkładu \\
\hline Warstwy istebniańskie (nierozdzielone) & 1566 & 1584 & 18 & & 67 & 65 & & & skały nadkładu \\
\hline Warstwy istebniańskie dolne & 1584 & 1746 & 162 & & 70 & 67 & & & skała macierzysta \\
\hline Podłoże & 1746 & 1800 & 54 & & 80 & 70 & & & skały podłoża \\
\hline
\end{tabular}

paleotemperatur na powierzchni ziemi, związane ze zmianą położenia badanego obszaru w historii geologicznej, a także zmianami paleoklimatu Ziemi (Hantschel i Kauerauf, 2009).

Rekonstrukcji paleostrumienia cieplnego dokonano, opierając się na pomiarach stopnia termicznego przeobrażenia substancji organicznej rozproszonej w skałach, umożliwiających kalibrację modelu (rys. 5). Ze względu na brak analiz refleksyjności witrynitu wartości te obliczono z pomiarów wskaźnika $\mathrm{T}_{\max }$ (uzyskanego z analizy Rock-Eval), według wzoru (1) (Wüst, 2013):

$$
R_{o \text { calc. }}=0,018 \cdot \mathrm{T}_{\max }-7,16
$$

Współczesną wartość strumienia cieplnego określono na podstawie pomiaru temperatury w otworze (rys. 6). W oparciu o przyjęty model paleotemperatur oraz paleobatymetrię możliwe było odtworzenie wartości paleotemperatur kontaktu woda-osad (sediment-water interface temperature) (rys. 4).

W kolejnym kroku przeprowadzono modelowanie procesu generowania węglowodorów. Głównym celem tego etapu jest określenie potencjału węglowodorowego wydzielonych skał macierzystych, co wiąże się z odtworzeniem warunków termicznych występujących w czasie geologicznym w wybranym punkcie basenu sedymentacyjnego odpowiadającym lokalizacji modelowanego profilu. Umożliwia to odtworzenie czasowych i głębokościowych granic dojrzałości, w jakich znalazła się skała macierzysta, a co za tym idzie - możliwa

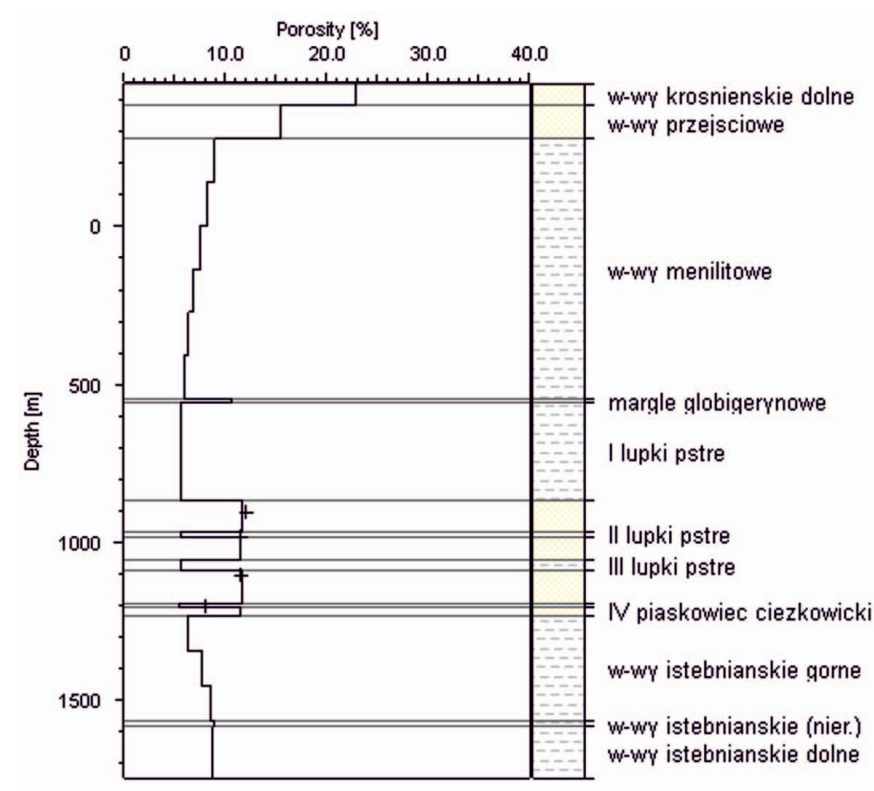

Rys. 3. Kalibracja modelu kompakcji w profilu odwiertu

Fig. 3. Compaction model calibration in the analysed borehole profile

jest symulacja procesów prowadzących do powstania węglowodorów.

W celu wykonania modelowania procesu generowania węglowodorów niezbędne jest zdefiniowanie skały macierzystej, co wiąże się z jej geochemiczną charakterystyką. Przeprowadza się ją na podstawie rekonstrukcji wartości 

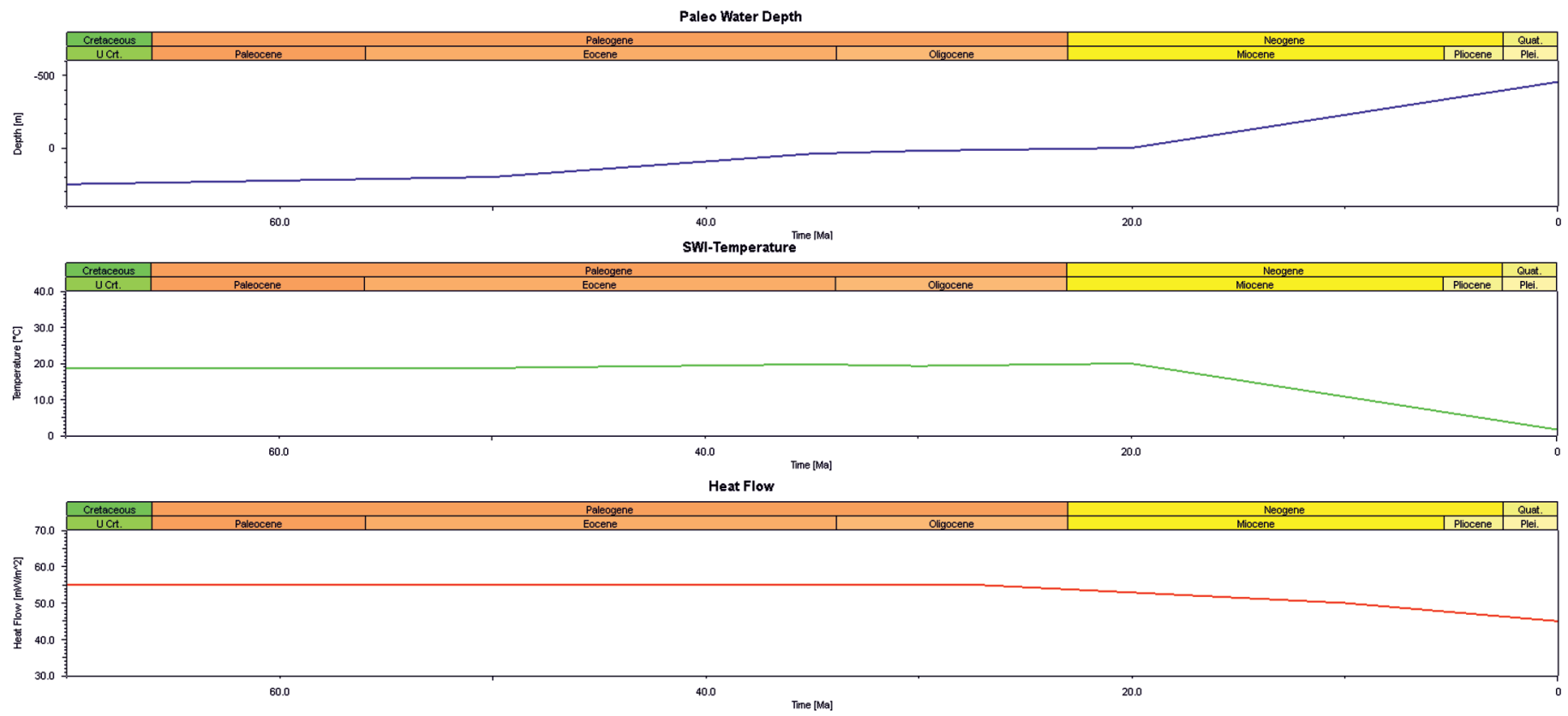

Rys. 4. Wykresy zmienności warunków brzegowych dla modelowanego otworu

Fig. 4. Boundary conditions assigned in the model

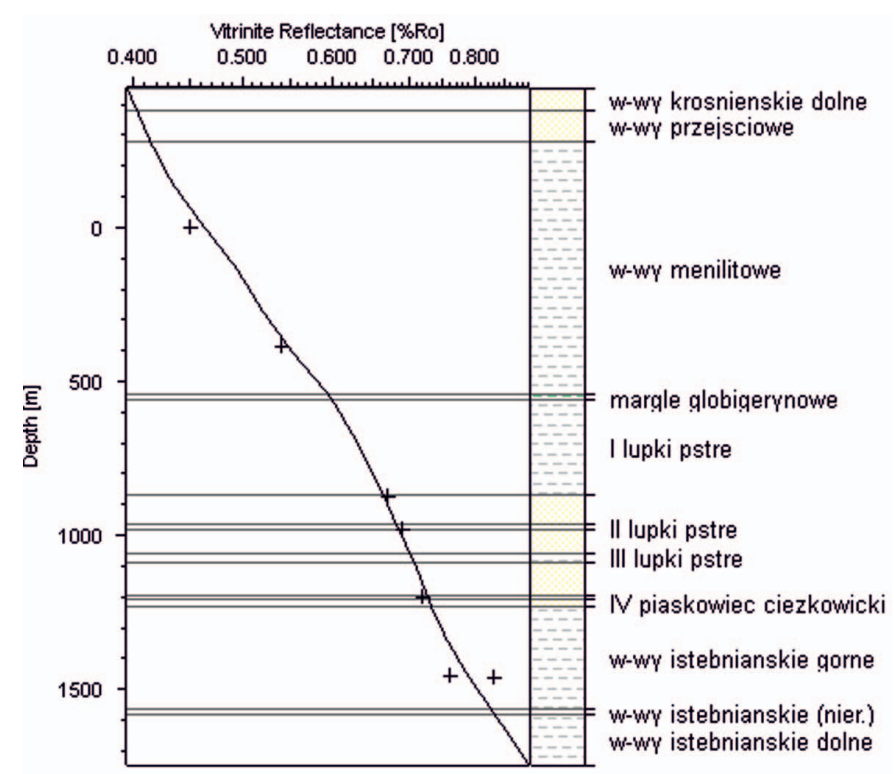

Rys. 5. Kalibracja modelu termicznego w profilu odwiertu

Fig. 5. Thermal model calibration in the analysed borehole profile

pierwotnego potencjału wodorowego kerogenu $\left(\mathrm{HI}_{0}\right)$, oszacowania początkowych zawartości węgla organicznego rozproszonego w skale $\left(\mathrm{TOC}_{0}\right)$, a także doboru modelu kinetycznego kerogenu. Model ten został dobrany spośród dostępnych w bibliotece programu PetroMod odpowiadających kerogenowi III typu. Geochemiczną charakterystykę substancji organicznej przeprowadzono na podstawie wyników pirolizy Rock-Eval próbek z modelowanego otworu (rys. 7). Jako skałę macierzysta przyjęto poziom dolnych warstw istebniańskich o miąższości $162 \mathrm{~m}$. Początkowy potencjał węglowodorowy oszacowano na $200 \mathrm{mg} \mathrm{HC/g} \mathrm{TOC,} \mathrm{natomiast} \mathrm{za} \mathrm{początkową}$

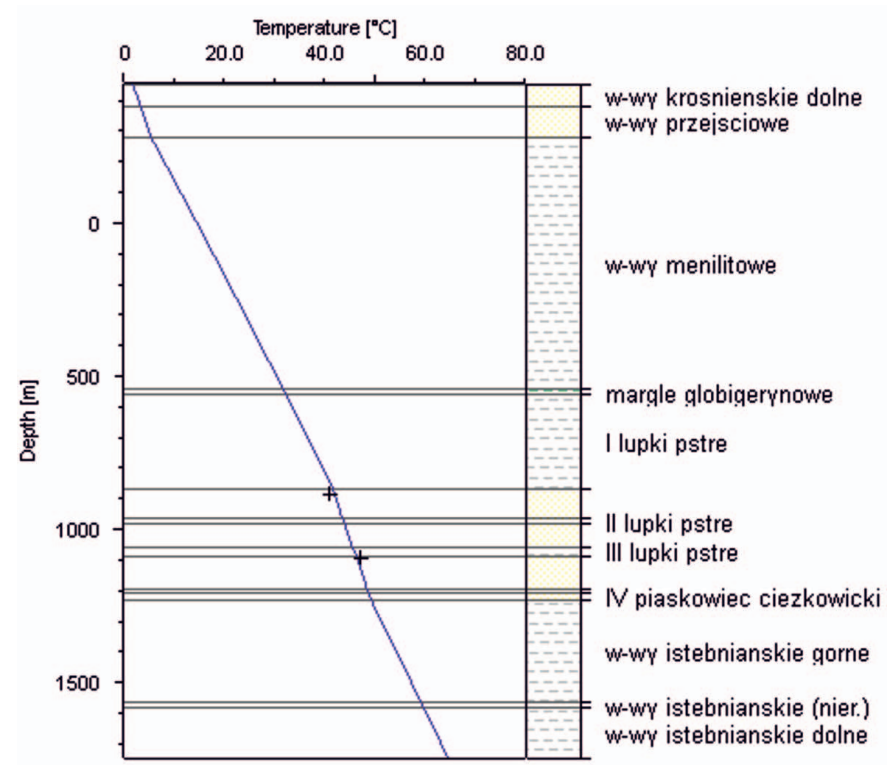

Rys. 6. Kalibracja modelu temperatury pomierzonymi wartościami w profilu otworu

Fig. 6. Calculated present-day borehole temperature calibrated against measurements

ilość węgla organicznego rozproszonego skale macierzystej przyjęto $2,70 \%$.

\section{Wyniki modelowania}

W wyniku przeprowadzonego modelowania uzyskano dane na temat stopnia transformacji kerogenu (TR), czasowych i głębokościowych przedziałów procesów generacyjnych oraz ilości wygenerowanych węglowodorów. 


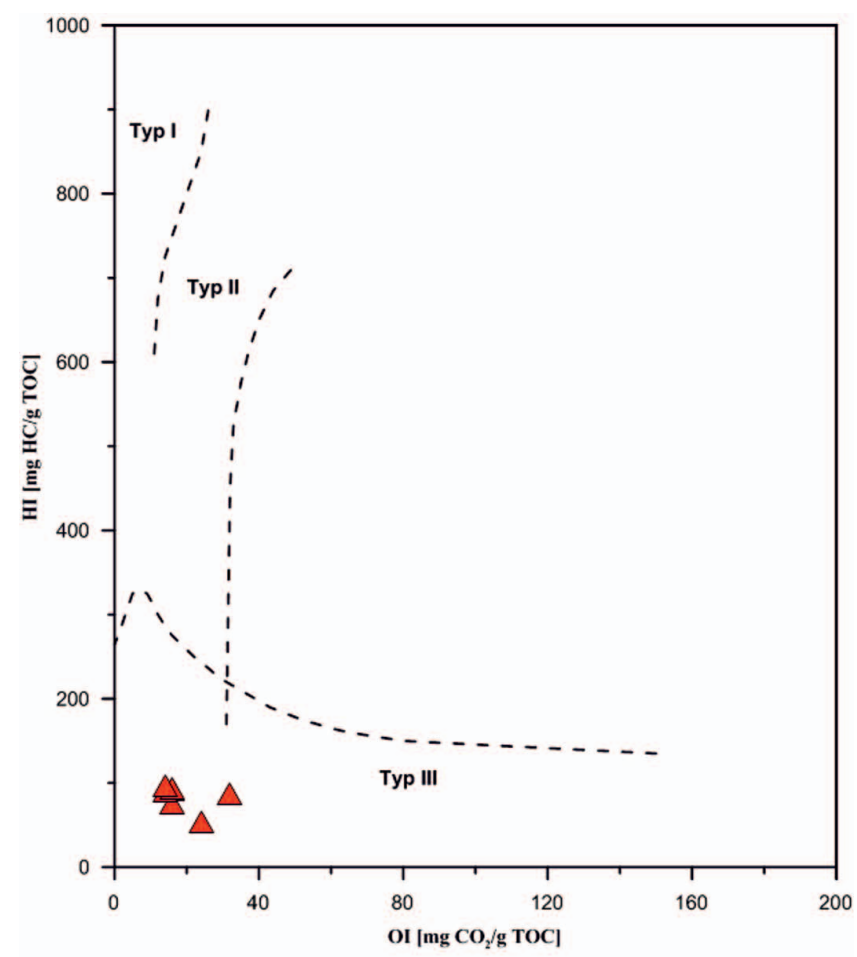

Rys. 7. Wykres korelacyjny OI i HI przedstawiający typ kerogenu zawartego w próbkach $\mathrm{z}$ modelowanego otworu

Fig. 7. OI and HI correlation plot showing the type of kerogen of the samples from the modeled borehole

Modelowanie wykazało, że poziom skał macierzystych pogrążony został na głębokość poniżej 2000 m (w której temperatura osiągnęła $100^{\circ} \mathrm{C}$ ) około $32,6 \mathrm{mln}$ lat temu, tj. w oligocenie. Temperatura ta odpowiada oknu ropnemu, i to właśnie wtedy łupki istebniańskie rozpoczęły generację węglowodorów. Maksymalna temperatura, którą osiągnął wydzielony interwał macierzysty, wynosiła około $140^{\circ} \mathrm{C}$, co odpowiada wartości 0,85\% w skali refleksyjności witrynitu (rys. 8). Głównym czynnikiem kontrolującym dojrzałość termiczną oraz transformację substancji organicznej, a co za tym idzie generację węglowodorów, było największe pogrążenie zbiornika na głębokość poniżej $4200 \mathrm{~m}$. Pogrążenie to doprowadziło do najwyższego tempa generowania węglowodorów i związane było z nagłą subsydencją dolnych warstw istebniańskich, spowodowaną osadzeniem się zerodowanych skał miocenu i skał młodszych. Rozpoczęcie procesów erozyjnych datuje się na około $20 \mathrm{mln}$ lat temu. Wydźwiganie się górotworu, będące następstwem erozji wyżej wymienionych utworów, nie zahamowało procesu generacji węglowodorów. Koniec generacji nastąpił około $10 \mathrm{mln}$ lat temu. Stopień transformacji kerogenu rozproszonego w skale osiągnął 29\% (rys. 9). Pogrążenie skały macierzystej doprowadziło do wygenerowania $0,62 \mathrm{mln}$ ton węglowodorów z $1 \mathrm{~km}^{2}$ skały o średniej miąższości $162 \mathrm{~m}$. Nieliniowy przyrost ilości generowanych węglowodorów $\mathrm{w}$ czasie pogrążania skał w miocenie związany jest $\mathrm{z}$ dobranym modelem kinetycznym dla kerogenu (rys. 10).

\section{Podsumowanie}

Jednowymiarowe modelowanie procesów naftowych wykorzystywane jest do rekonstrukcji rozwoju basenu sedymentacyjnego w skali pojedynczego otworu. Zastosowanie opracowanego modelu umożliwia szacowanie ilości wygenerowanych węglowodorów, czasu początku i końca generacji oraz głębokości, na jakiej miała ona miejsce, a także stopnia wyczerpania potencjału węglowodorowego skały, wyrażonego stopniem

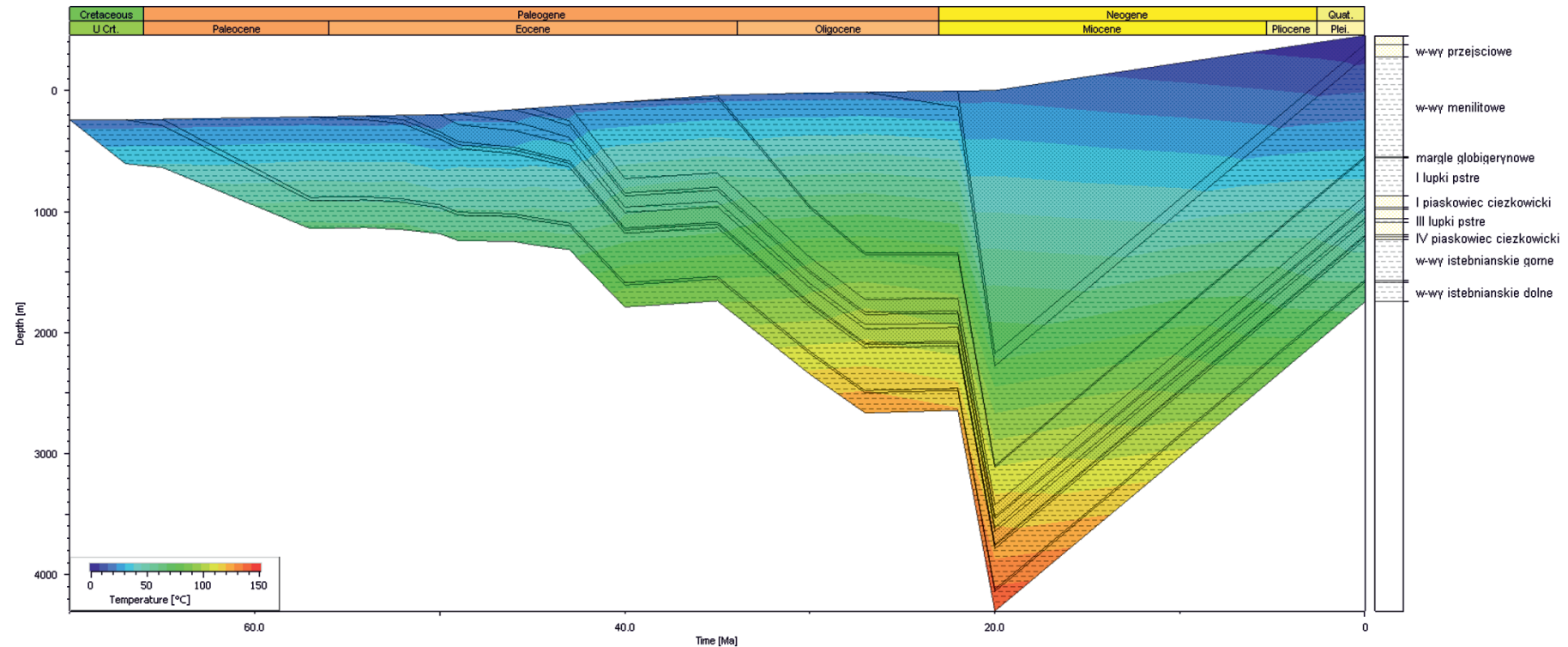

Rys. 8. Rozkład temperatury w czasie w profilu modelowanego otworu

Fig. 8. Temperature plot in the analysed borehole profile 


\section{NAFTA-GAZ}

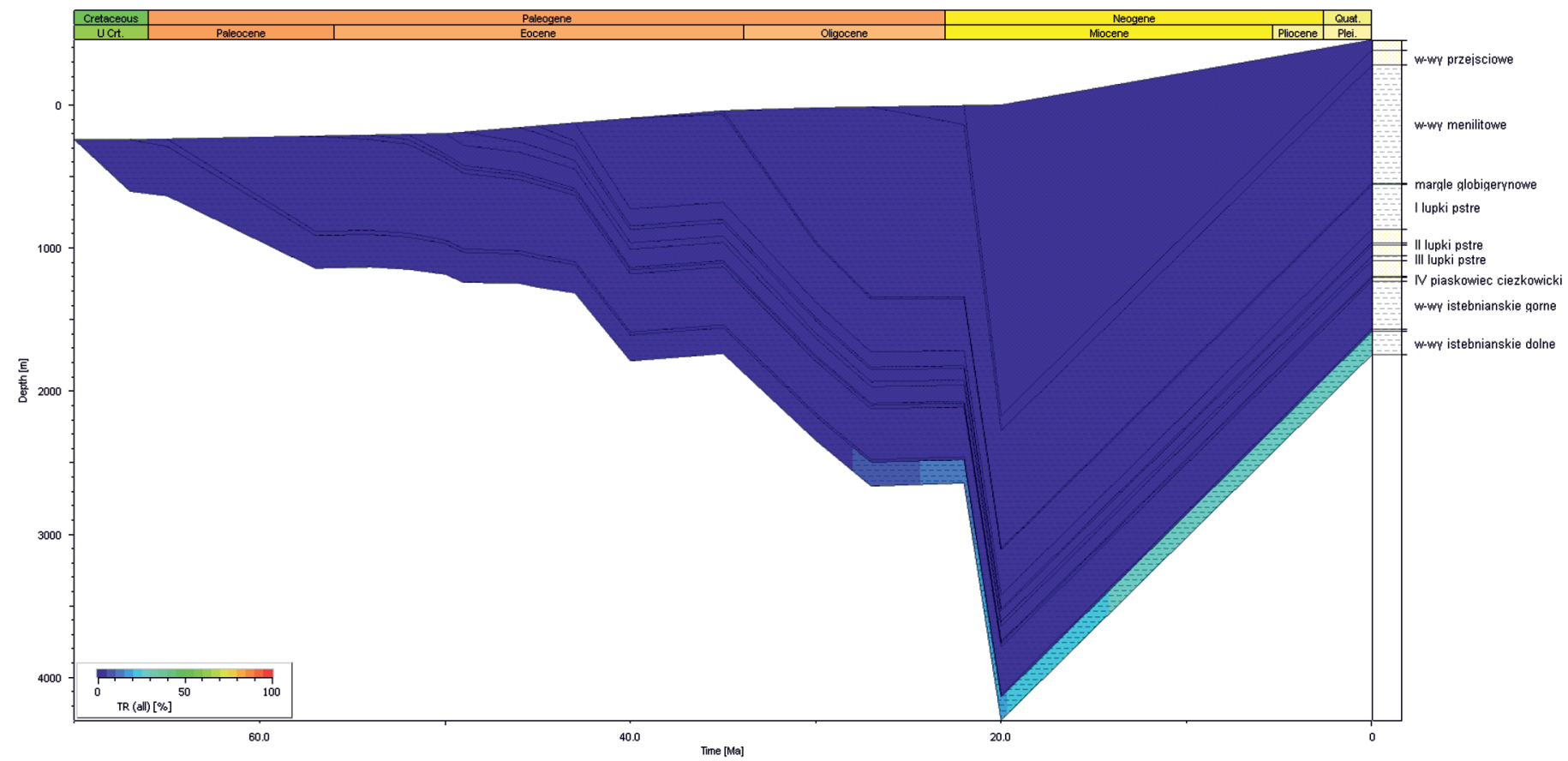

Rys. 9. Zmiana stopnia transformacji kerogenu w czasie w profilu modelowanego otworu

Fig. 9. Transformation ratio plot of kerogen in the analysed borehole profile

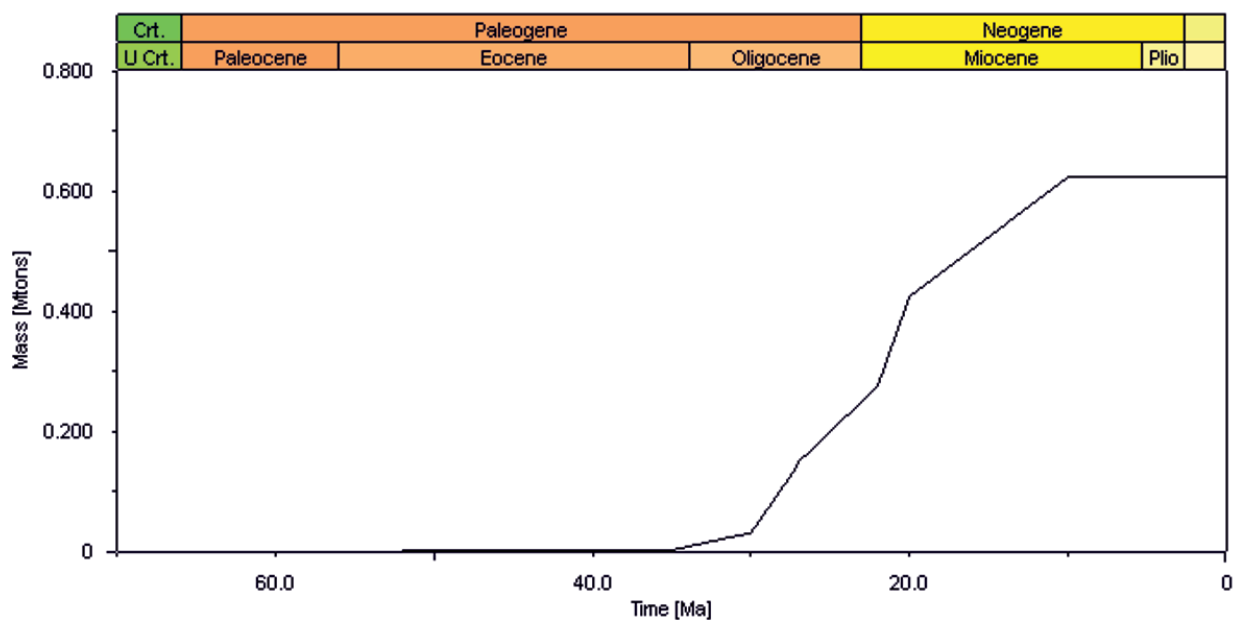

Rys. 10. Skumulowana wydajność procesu generowania węglowodorów ze skały macierzystej z profilu modelowanego otworu

Fig. 10. Cumulative hydrocarbon mass generation plot

transformacji kerogenu. Kluczowym elementem determinującym uzyskane w procesie symulacji wyniki jest w miarę możliwości jak najwierniejsza rekonstrukcja pierwotnego potencjału wodorowego $\left(\mathrm{HI}_{0}\right)$ oraz pierwotnej zawartości substancji organicznej $\left(\mathrm{TOC}_{0}\right)$. Również dobór modelu kinetycznego kerogenu ma istotny wpływ na obliczone ilości wygenerowanych węglowodorów oraz czas ich generacji. Przyjęte wielkości erozji i paleomiąższości zerodowanych utworów są kluczowym elementem modelu, determinującym warunki termiczne, w jakich znajdowała się skała macierzysta. Niewątpliwie istotnym i nierzadko trudnym zadaniem jest rekonstrukcja paleobatymetrii badanego obszaru, gdyż ma ona bezpośredni wpływ na paleotemperatury kontaktu woda-osad oraz na rozwój porowatości skał budujących model. W wyniku przeprowadzonego modelowania stwierdzono, że generacja węglowodorów rozpoczęła się w oligocenie, a ilość wygenerowanych produktów wynosiła $0,62 \mathrm{mln}$ ton z $1 \mathrm{~km}^{2}$ skały o miąższości $162 \mathrm{~m}$.

Artykuł powstał na podstawie pracy statutowej pt.: Geochemiczna charakterystyka próbek warstw istebniańskich z centralnej części jednostki śląskiej $w$ kontekście ich macierzystości - praca INiG - PIB na zlecenie MNiSW; nr zlecenia: 0060/SG/2019, nr archiwalny: DK-4100-0050/2019.

\section{Literatura}

Bąk K., Bąk M., Paul Z., 2001. Barnasiówka Radiolarian Shale Formation - a new lithostratigraphic unit in the Upper Cenomanian - lowermost Turonian of the Polish Outer Carpathians (Silesian Series). Ann. Soc. Geol. Pol., 71: 75-103.

Bieda F., Geroch S., Koszarski L., Książkiewicz M., Żytko K., 1963. Stratigraphy of the Polish Outer Carpathians. Biuletyn Instytutu Geologicznego, 181: 51-74. 
Brzuszek P., 2015. Interpretation of petroleum system modeling technique in shale gas resources assessment. Nafta-Gaz, 6: 408-417.

Cieszkowski M., 1992. Strefa Michalczowej - nowa jednostka strefy przedmagurskiej w Zachodnich Karpatach Fliszowych i jej geologiczne otoczenie. Kwartalnik AGH ,, Geologia”, 18(1-2): 1-125.

Dziadzio P., 2015. Śródmenilitowe piaskowce magdaleńskie jako przykład płytkowodnej sedymentacji deltowej w Karpatach. Nafta-Gaz, 9: 624-631.

Dziadzio P., 2018. Środowisko sedymentacji warstw menilitowych w profilu łuski Stróż, jednostka śląska, Karpaty. Nafta-Gaz, 11: 813-820. DOI: 10.18668/NG.2018.11.05.

Dziadzio P., Borys Z., Kuk S., Masłowski E., Probulski J., Pietrusiak M., Górka A., Baszkiewicz A., Karnkowski P., Karnkowski P.H., Pietrusiak M., 2006. Hydrocarbon Resources of the Polish Outer Carpathians - Reservoir Parameters, Trap Types, and Selected Hydrocarbon Fields: A Stratigraphic Review. The Carpathians and their foreland: Geology and hydrocarbon resources. AAPG Memoir, 84: 25-291. DOI: 10.1306/985611M843071.

Golonka J., Waśkowska-Oliwa A., 2007. Stratygrafia polskich Karpat fliszowych pomiędzy Bielskiem-Białą a Nowym Targiem. Kwartalnik AGH ,, Geologia”, 33(4/1): 5-28.

Hantschel T., Kauerauf A., 2009. Fundamentals of Basin and Petroleum Systems Modeling. Springer-Verlag, Berlin-Heidelberg: 1-434.

Hanzlíková E., 1966. Die Foraminiferen der Lhoty Schichten. Acta Musei Moraviae, 51: 95-132.

Hermanrud C., 1993. Basin modeling techniques - an overview. NPF Special Publication, 3: 1-34.

Jankowski L., 1996. Budowa geologiczna jednostki śląskiej między Jodłówką Tuchowską a Szerzynami. Biuletyn Państwowego Instytutu Geologicznego, 374: 5-19.

Jankowski L., Probulski J., 2011. Rozwój tektoniczno-basenowy Karpat zewnętrznych na przykładzie budowy geologicznej złóż Grabownica, Strachocina i Łodyna oraz ich otoczenia. Geologia, 37: 555-583.

Jucha S., Kotlarczyk J., 1961. Seria menilitowo-krośnieńska w Karpatach fliszowych. Prace Geologiczne Komisji Nauk Geologicznych PAN, Oddziat w Krakowie, 4: 1-115.

Karnkowski P., 1993. Złoża gazu ziemnego i ropy naftowej w Polsce. Karpaty i zapadlisko przedkarpackie. Towarzystwo Geosynoptyków „Geos” AGH.

Koszarski L., Żytko K., 1959. Uwagi o rozwoju i pozycji stratygraficznej łupków jasielskich w serii menilitowo-krośnieńskiej Karpat Środkowych. Kwartalnik Geologiczny, 3(4): 996-1015.

Kosakowski P., Więcław D., Kotarba M.J., 2009. Charakterystyka macierzystości wybranych utworów fliszowych w przygranicznej strefie polskich Karpat Zewnętrznych. Geologia, 35: 155-190.

Kotarba M.J., Więcław D., Dziadzio P., Kowalski A., Bilkiewicz E., Kosakowski P., 2014. Organic geochemical study of source rocks and natural gas and their genetic correlation in the central part of the Polish Outer Carpathians. Marine and Petroleum Geology, 45: 106-120. DOI: 10.1016/j.marpetgeo.2014.03.014.

Menčík E., Adamová M., Dvořák J., Dudek A., Hanzlíková E., Houša V., Jetel J., Jurková A., Hanzlíková A., Houša E., Peslová V., Rybářová H., Šmíd L., Šebesta B.,Tyřáček J., Vašíček, Z., 1983. Geologie Moravskoslezských Beskyd a Podbeskydské pahorkatiny. Academia, Praha: 1-304.
Olszewska B., Szydło A., Jugowiec-Nazarkiewicz M., Nescieruk P., 2008. Zintegrowana biostratygrafia węglanowych osadów warstw cieszyńskich w polskich Karpatach Zachodnich. Kwartalnik AGH „,Geologia”, 34(3/1): 33-59.

Oszczypko N., 2011. Charakterystyka tektoniczna i geologiczna polskich Karpat Zachodnich. [W:] Górecki W. (red.). Atlas zasobów wód i energii geotermalnej Karpat Zachodnich. Wydawnictwo GOLDDRUK, Kraków: 62-81.

Picha F., Stranik Z., Krejčio O., 2006. Geology and hydrocarbon resources of the Outer Western Carpathians and their foreland, Czech Republic. The Carpathians and their foreland: Geology and hydrocarbon resources. American Association of Petroleum Geologists, Memoir, 84: 49-175.

Pszonka J., Wendorff M., 2017. Carbonate cements and grains in submarine fan sandstones - the Cergowa Beds (Oligocene, Carpathians of Poland) recorded by cathodoluminescence. International Journal of Earth Science, 106: 269-282. DOI: 10.1007/s00531-016-1318-z.

Skupien P., 2003. Palynologie tithonu - spodního hauterivu slezské jednostky na profilu Skalice. Sborník védeckých praci Vysoké Školy báňské - Technické Univerzity Ostrava, Řada hornickogeologická, 49, 8: 15-31.

Spunda K., Matyasik I., 2019. Geochemiczna charakterystyka próbek z warstw istebniańskich jako skał potencjalnie macierzystych. Nafta-Gaz, 3: 139-149. DOI: 10.18668/NG.2019.03.02.

Waśkowska A., 2015. The Eocene Hieroglyphic Beds of the Silesian Nappe in the Western Polish Carpathians - their development and foraminiferal record. Geological Quarterly, 59: 271-299. DOI: $10.7306 /$ gq. 1213.

Welte D.H., Yükler M.A., Radke M., Leythaeuser D., Mann U., Ritter U., 1983. Organic geochemistry and basin modelling; important tools in petroleum evaluation. [W:] J. Brooks (ed.). Petroleum Geochemistry and Exploration of Europe. Geol. Soc. London Special Publication: 237-252.

Wüst A.J., 2013. Vitrinite reflectance versus pyrolysis Tmax data: Assessing thermal maturity in shale plays with special reference to the Duvernay shale play of the Western Canadian Sedimentary Basin, Alberta, Canada. Society of Petroleum Engineers. DOI: 10.2118/167031-MS.

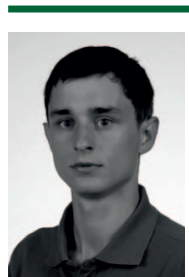

Mgr inż. Karol SPUNDA

Asystent w Zakładzie Geologii i Geochemii Instytut Nafty i Gazu - Państwowy Instytut Badawczy ul. Lubicz 25 A

31-503 Kraków

E-mail: karol.spunda@inig.pl 